Kazimierz Panuś ${ }^{1}$

Uniwersytet Papieski Jana Pawła II w Krakowie

Maciej Radej²

Uniwersytet Papieski Jana Pawła II w Krakowie

\title{
Miejsca przepowiadania słowa Bożego. Panorama historyczna
}

Różne były miejsca, z których kaznodzieje w ciągu wieków przybliżali wiernym zbawienie dokonane w Chrystusie. Do wyboru określonej lokalizacji skłaniały ich zaistniałe pewne okoliczności. W niniejszym artykule przedstawione zostaną najpierw miejsca głoszenia słowa Bożego przez Jezusa, apostołów i Kościół pierwszych wieków. Następnie przybliżone będą miejsca proklamacji słowa Bożego w średniowieczu i w czasach nowożytnych. W końcu na tym tle ukazany zostanie wysiłek ewangelizacyjny Kościoła w Polsce. W tak nakreślonej panoramie historycznej zapoznać się będzie można zarówno ze zwyczajami przejętymi z innych krajów europejskich, jak też dostrzec polski wkład w tę problematykę.

1 Ksiądz Kazimierz Panuś, prof. zw. dr hab., prezes Polskiego Towarzystwa Teologicznego w Krakowie, kierownik Katedry Homiletyki Wydziału Teologicznego UPJPII. Autor wielu publikacji z zakresu homiletyki, historii kaznodziejstwa i hagiografii. E-mail: kazimierz.panus@upjp2.edu.pl.

2 Ksiądz Maciej Radej, kapłan diecezji kieleckiej, stopień doktora teologii w zakresie homiletyki uzyskał na Wydziale Teologicznym UPJPII. E-mail: richtis@op.pl. 


\section{Miejsca głoszenia słowa Bożego przez Jezusa}

Niedościgłym wzorem wszystkich kaznodziejów jest Jezus z Nazaretu. Wertując ewangelie, łatwo zauważyć, że głosił On słowo Boże nie tylko w świątyni jerozolimskiej (por. Mt 26, 55) i w synagogach, w których zbierano się na modlitwę i czytanie Pisma Świętego (por. Łk 4, 15; 4, 44; 6, 6). Słynne było zwłaszcza Jego wystąpienie w synagodze w Nazarecie (Łk 4, 16-30), a więc w mieście, w którym się wychował. Synagogi nie były jednak jedynym miejscem, w których przemawiał Jezus. Była nią często łódź Szymona, do której wsiadał, chroniąc się pod napierającym tłumem. Z tej to „łodzi nauczał tłumy” (Łk 5, 3) w przepięknej scenerii jeziora Genezaret. Innym jeszcze miejscem głoszenia słowa Bożego przez Jezusa była równina, na której się zatrzymał z wielkim tłumem uczniów i mnóstwem ludu z całej Judei, i z Jeruzalem, z nadmorskiego Tyru i Sydonu (por. Łk 6, 17) ${ }^{3}$. Na jednym z takich wzniesień Jezus wygłosił swoje słynne Kazanie na górze (por. Mt 5, 1-2). Badania biblistów wskazują, że miejscem wygłoszenia tego kazania było jedno ze wzgórz znajdujących się w okolicy Kafarnaum, tzw. Góra Błogosławieństw. Ma ona około 150 metrów wysokości i leży w odległości 3 km na zachód od Kafarnaum. Świadectwa tradycji na rzecz tego miejsca sięgają IV wie$\mathrm{ku}^{4}$. Adresatami Kazania na górze byli przede wszystkim uczniowie. Tekst jednak wyraźnie podkreśla, że były tam także tłumy ludu.

Ewangelista Łukasz akcentuje jeszcze dwa nietypowe miejsca głoszenia słowa Bożego przez Jezusa. Są nimi dom (Łk 10, 38-42) oraz uczta (Łk 14, 1-24)5. Te kolejne dwa miejsca głoszenia i słuchania słowa Jezusa stwarzały bezpośrednią i braterską wspólnotę, ułatwiając recepcję przekazywanego orędzia. Akcent położony na dom i ucztę jako miejsca głoszenia słowa Bożego znalazł swoją pełnię w Ostatniej Wieczerzy i ustanowionej w jej trakcie Eucharystii.

3 M. Radej, Istotne problemy kaznodziejskie, Kraków 2013, s. 124.

4 Ewangelia według św. Mateusza, wstęp, przekład z oryginału, komentarz J. Homerski, Poznań-Warszawa 1979, s. 123.

5 Zob. E. Staniek, Ewangeliczne uczty, Kraków 2008. 


\section{Miejsca głoszenia słowa Bożego przez apostołów i Kościół pierwszych wieków}

Apostołowie, ukształtowani w "Jezusowej szkole kaznodziejskiej” i posłani na cały świat, by „głosić Ewangelię wszelkiemu stworzeniu” (Mk 16, 15), starali się naśladować swego Mistrza. Prawdę, że „nie dano ludziom pod niebem żadnego innego imienia, w którym mogliby być zbawieni, jak tylko imię Jezus" (Dz 4,12), głosili najpierw w synagogach. Po swym nawróceniu także św. Paweł „zaczął głosić w synagogach, że Jezus jest Synem Bożym" (Dz 9, 20). Barnaba i Szaweł, gdy przybyli do Salaminy na Cyprze, „głosili słowo Boże w synagogach żydowskich” (Dz 13, 5). Podobnie czynili w Antiochii Pizydyjskiej (Dz 13, 14-16), w Ikonium i w Tesalonice „przez trzy szabaty” (Dz 17, 2)

Napotykając jednak na coraz większy opór ze strony środowisk żydowskich, zaczęli nauczać pogan. W ten sposób pojawiła się pilna potrzeba znalezienia miejsca, z którego mogłaby być głoszona Ewangelia. W Filippi, głównym mieście Macedonii, było nim miejsce nad rzeką. „W szabat wyszliśmy za bramę nad rzekę, gdzie - jak sądziliśmy - było miejsce modlitwy. I usiadłszy, rozmawialiśmy z kobietami, które się zeszły" (Dz 16, 12-14).

Wzorem Jezusa także apostołowie głosili słowo Boże w domach ${ }^{7}$. Dzieje Apostolskie opowiadają, że chrześcijanie „łamali chleb po domach” (Dz 2, 46). Przykładem tego jest wielogodzinny, niestrudzony przekaz słowa Bożego przez św. Pawła wspólnocie chrześcijańskiej w Troadzie, zgromadzonej na łamanie chleba (Dz 20, 7. 11).

Kolejnym miejscem, na którym św. Paweł głosić będzie zbawienie dokonane w Jezusie Chrystusie, będzie agora (gr. ỏyopó), a więc główny plac, rynek w miastach starożytnej Grecji, centrum, wokół którego toczyło się życie polityczne, religijne, a czasami także handlowe. Do najbardziej znanych należała agora ateńska. To na nią przychodził codziennie Paweł, podejmując z chętnymi dyskusję na tematy wiary (Dz 17, 17).

6 M. Radej, Istotne problemy kaznodziejskie, dz. cyt., s. 124-125.

7 J. Daniélou, H. I. Marrou, Historia Kościoła, t. 1: Od początków do roku 600, tłum. M. Tarnowska, Warszawa 1986, s. 28. 
Na rynku Apostoł Narodów spotkał także przedstawicieli dwóch ówczesnych szkół filozoficznych o podłożu materialistycznym: epikurejczyków i stoików, wśród których nauka głoszona przez niego wzbudziła ogromne zainteresowanie. Filozofowie epikurejscy i stoiccy zaprowadzili go na kolejne ważne miejsce Aten, na areopag (por. Dz 17, 18-20). Na tym miejscu, gdzie zwykle odbywały się zebrania o charakterze politycznym, handlowym czy kulturalnym, św. Paweł mówił o „Nieznanym Bogu” (Dz 17, 23). Wobec ludzi czuwających nad poprawnością doktryny mógł przedstawić publicznie naukę Chrystusa, której wszyscy byli bardzo ciekawi .

Kolejnym nietypowym miejscem głoszenia Ewangelii było więzienie. Już w Filippi Paweł i Sylas zamknięci w lochu „modlili się, śpiewając hymny Bogu" (Dz 16, 25), a inni więźniowie przysłuchiwali się im. Po trzęsieniu ziemi strażnik więzienia dostąpił łaski nawrócenia. Paweł i Sylas „opowiedzieli więc naukę Pana jemu i wszystkim jego domownikom" (Dz 16, 32). Także ostatnie lata życia Apostoła Narodów połączone były z domowym aresztem, w którym „przyjmował wszystkich, którzy do niego przychodzili, głosząc królestwo Boże i nauczając o Panu Jezusie Chrystusie zupełnie swobodnie, bez przeszkód" (Dz 28, 31) ${ }^{9}$.

Te miejsca nauczania apostolskiego podjął Kościół pierwszych wieków, dołączając do nich jeszcze kilka nowych. Podczas prześladowań chrześcijan takim ważnym miejscem w rejonie Rzymu były katakumby, podziemne cmentarze, w których chowano zmarłych ${ }^{10}$. Mowy pochwalne na cześć męczenników głoszono często w miejscach ich śmierci (martyriach), a katechumeni przyjmowali część wtajemniczenia chrześcijańskiego w baptysteriach ${ }^{11}$.

8 M. Radej, Istotne problemy kaznodziejskie, dz. cyt., s. 126.

9 M. Radej, Istotne problemy kaznodziejskie, dz. cyt., s. 126.

10 B. Iwaszkiewicz-Wronikowska, Katakumby, w: Encyklopedia katolicka, t. 8, red. A. Bednarek i in., Lublin 2000, s. 978-982.

11 A. Olivar, Predicazione: Nella Chiesa Antica, w: Dizionario di Omiletica, a cura di M. Sodi, A. M. Triacca, Torino-Bergamo 1998, s. 1218. 


\section{Miejsca proklamacji słowa Bożego w późniejszych wiekach}

Z chwilą uzyskania przez Kościół wolności działania miejscem przepowiadania stały się przede wszystkim świątynie i umieszczone w nich specjalnie wyeksponowane ambony ${ }^{12}$. Wywodzą się one bądź z pulpitów stosowanych przez lektorów w świeckich szkołach, bądź też od żydowskiej bimy (bemy), czyli podestu, z którego odczytywano Pismo Święte ${ }^{13}$. Kult sprawowany w pogańskich świątyniach greckich czy rzymskich nie wymagał takiego sprzętu. Tymczasem $w$ liturgii synagogalnej był on potrzebny do odczytywania ksiąg świętych. Pierwowzorem ambony może być podwyższenie, z którego kapłan Ezdrasz odczytywał repatriantom z niewoli babilońskiej Księgę Prawa (por. Ne 8, 4-5).

Ambona wspomniana jest po raz pierwszy w postanowieniach synodu w Laodycei z 371 roku. Domagają się one traktowania jej z powaga i pozwalają wstępować na nią jedynie spełniającym obowiązek czytania Pisma Świętego lub śpiewania psalmów. Odtąd świadectw o ambonie tak w Kościele wschodnim, jak i zachodnim jest coraz więcej. Jedna z najbardziej znanych znajduje się w słynnej bazylice Sant'Apollinare Nuovo w Rawennie. Ma kształt trybuny, z parapetem wspartym na kolumnach. Ambony romańskie zdobiły inkrustacje z różnobarwnych marmurów, figury ptaków, zwłaszcza we Włoszech, oraz płaskorzeźby wyobrażające sceny ze Starego i Nowego Testamentu. W okresie wczesnego gotyku pojawiły się ambony przyścienne, a także w formie loggii i balkonów.

12 Jak podkreśla B. Nadolski, Ambona, historia, znaczenie, symbolika, Kraków 2008, s. 14-16, termin „ambona” wywodzi się od greckiego słowa anabainein, które oznacza „wstępować na podwyższenie". Czasem wyprowadza się jej nazwę od łacińskiego słowa ambio, co oznacza „otaczać” od barierki, która otaczała stojącego na podwyższeniu lektora, bądź od greckiego słowa ambon, tzn. szczyt wzgórza. Oprócz tej najbardziej rozpowszechnionej i znanej po dzień dzisiejszy nazwy funkcjonowały i inne, takie jak: pulpitum, suggestus, pluteus, pyrgus, absida, exedra, auditorium, tribunal, dicterium, lectricium, legitorium, analogium. Każda z tych historycznych nazw akcentowała jakiś specyficzny aspekt owego centralnego miejsca przeznaczonego dla liturgii słowa. Zob. także G. Siwek, Interpretacja homiletyczna miejsc przepowiadania w przestrzeni kościelnej, „Analecta Cracoviensia” 36 (2004), s. 300; B. Snela, Ambona, w: Encyklopedia katolicka, t. 1, red. F. Gryglewicz, R. Łukaszyk, Z. Sułowski, Lublin 1973, s. 407.

13 B. Nadolski, Ambona, historia, znaczenie, symbolika, dz. cyt., s. 13. 
Od średniowiecza ambona stała się głównym miejscem przepowiadania słowa Bożego ${ }^{14}$. Umieszczano ją w pobliżu ołtarza, gdyż miała za zadanie także umożliwiać maksymalny kontakt mówcy ze słuchaczami. Troska o słyszalność i komunikację z uczestnikami liturgii wyrażała się w podnoszeniu ambony w prezbiterium, a następnie w nawie kościoła. Jak podkreśla Bogusław Nadolski, podwyższenie to motywowano także odwołaniem się do słów proroka Izajasza: „Wstąpże na wysoką górę, zwiastunko dobrej nowiny w Syjonie. Podnieś mocno twój głos, zwiastunko dobrej nowiny w Jeruzalem" (Iz 40, 9) ${ }^{15}$.

Średniowiecze stworzyło wiele wspaniałych kazalnic, a więc miejsc służących przede wszystkim głoszeniu słowa Bożego. Niektóre znich są prawdziwymi dziełami sztuki. Taką jest ambona w katedrze w Akwizgranie, ufundowana przez cesarza Henryka II w 1014 roku. Złocona, wysadzana kamieniami, gemmami i antycznymi plakietami z kości słoniowej, stanowi prawdziwe tabernakulum słowa Bożego. Inna słynna ambona średniowieczna znajdowała się w austriackim opactwie Klosterneuburg. Jej dekorację stanowiły 52 metalowe płytki, na których techniką żłobinowej emalii przedstawiono zespół scen ze Starego i Nowego Testamentu powiązanych zasadami typologicznymi w taki sposób, że każda scena Nowego Testamentu zapowiadana jest przez wydarzenie ze Starego Testamentu. Te niewielkie, wysokości kilkunastu centymetrów, kwatery zawierają łącznie dziesiątki żywo poruszających się postaci, składających się na jedyne w swoim rodzaju kompendium ikonografii, gestów, ekspresji. To najsłynniejsze dzieło złotnika lotaryńskiego Nicolasa z Verdun. Ukończone zostało w 1181 roku, dzisiaj zdobi ołtarz klosterneuburski ${ }^{16}$.

14 Najbogatsze zarówno w kształtach, jak i dekoracjach, są ambony barokowe i rokokowe; na ogół przyścienne, mają kształt kielicha kwiatu, paszczy ryby, łodzi św. Piotra (np. w kościołach św. Andrzeja w Krakowie i Wizytek przy Krakowskim Przedmieściu w Warszawie). Niezwykle interesujące są barokowa ambona w kościele dominikanów w Wilnie, połączona integralnie ze znajdującym się pod nią konfesjonałem oraz barokowa ambona w Pelplinie, której podest wsparty jest na głowie Samsona rozdzierającego lwa. Znacznie skromniejsze, zgodnie z duchem architektury tej epoki, są ambony doby klasycyzmu. Zob. K. Panuś, Zarys historii kaznodziejstwa w Kościele katolickim, cz. 1: Kaznodziejstwo w Kościele powszechnym, Kraków 1999, s. 201.

15 B. Nadolski, Ambona, historia, znaczenie, symbolika, dz. cyt., s. 21.

16 K. Panuś, Historia kaznodziejstwa, Kraków 2007, s. 154. 
W dojrzałym średniowieczu wychodzono także z głoszeniem słowa Bożego na zewnątrz świątyni. Zmuszały do tego kaznodziejów nadzwyczajne potrzeby ${ }^{17}$. Głoszenie słowa Bożego pod gołym niebem nabrało rozmachu wraz z rozwojem praktyki kaznodziejstwa wędrownego. Zapoczątkowali je Piotr Eremita (zm. 1115), Fulkon z Neuilly (zm. 1201), a zwłaszcza Robert z Arbrissel (zm. 1115). Kaznodzieje wędrowni, nie mogąc pomieścić swoich słuchaczy w obrębie świątyń, stawiali krzyże na rozstajach dróg, na cmentarzach i dziedzińcach kościelnych. W tej scenerii wzywali do nawrócenia i przemiany życia ${ }^{18}$.

Nową okolicznością skłaniającą do wyjścia z głoszeniem słowa Bożego poza mury świątyni stało się zwoływanie krucjat. Przykład nauczania poza świątynią dał sam papież bł. Urban II (zm. 1099). 27 listopada 1095 roku na synodzie we francuskim Clermont wezwał on katolicką Europę do wyprawy krzyżowej w celu odzyskania z rąk muzułmanów miejsc uświęconych życiem i śmiercią Jezusa Chrystusa. Jak podkreśla Steven Runciman, zbiegło się wówczas tak wielu duchownych i świeckich, że nie pomieścili się w katedrze, w której odbywały się sesje synodu. Ustawiono więc tron papieski na podium wzniesionym na błoniach za wschodnią bramą miasta i kiedy zebrały się nieprzebrane tłumy, Urban podniósł się, aby do nich przemówić ${ }^{19}$.

Podobny niezwykły napływ wiernych towarzyszył zwoływaniu II krucjaty, w Vézelay 31 marca 1146 roku. Wieść, że św. Bernard z Clairvaux wygłosi kazanie, ściągnęła do tego burgundzkiego miasteczka przybyszów z całej Francji. Podobnie jak przed pół wiekiem w Clermont, także i tu zebrała się tak wielka rzesza ludzi, że nie pomieściła się w słynnym romańskim kościele pielgrzymkowym św. Marii Magdaleny. Święty Bernard przemawiał z mównicy, którą mu zbudowano na błoniach u stóp tej świątyni ${ }^{20}$.

17 M. Radej, Istotne problemy kaznodziejskie, dz. cyt., s. 129.

18 J. Longère, La prédication médiévale, Paris 1983, s. 78.

19 S. Runciman, Dzieje wypraw krzyżowych, t. 1: Pierwsza krucjata i założenie Królestwa Jerozolimskiego, przekł. J. Schwakopf, Warszawa 1987, s. 107.

20 S. Runciman, Dzieje wypraw krzyżowych, t. 2: Królestwo Jerozolimskie i frankijski Wschód 1100-1187, przekł. J. Schwakopf, Warszawa 1987, s. 228. 
Kazania propagujące krucjaty uznawały za honor śmierć w obronie Jerozolimy i Ziemi Świętej. Wojownik chrześcijański, broniący współziomków od muzułmańskich najeźdźców, postrzegany był jako wybawiciel. Historia krucjat uzupełniła ten wizerunek, doprowadzając go do perfekcji. W wysiłku związanym z wyprawami krzyżowymi znaczącą rolę odegrali mnisi, w których duchowości dominowały odrzucenie świata, droga ascezy i kontemplacji Pisma Świętego. To z ich szeregów wywodzili się propagatorzy i główni ideolodzy walki o wyzwolenie świętych miejsc chrześcijaństwa. Ludzie ci znali i czytali codziennie Ewangelię oraz dzieła ojców Kościoła. Takimi byli wspomniani wyżej Piotr Eremita, przywódca duchowy krucjaty z roku 1096, wywodzący się z klasztoru w Cluny papież Urban II czy wreszcie św. Bernard z Clairvaux, uznawany za filar krucjat $^{21}$.

Podobne kaznodziejstwo prowadził Jakub z Vitry, zwołując w 1213 roku krucjatę przeciw herezji katarów (albigensów) ${ }^{22}$. Nie inaczej było w Hiszpanii podczas rekonkwisty. Wzywając lud do sięgnięcia po broń przeciwko „niewiernym, wrogom krzyża Chrystusowego”, jak zwykło się określać muzułmanów, kaznodzieje występowali w miejscach otwartych, kładąc nacisk na najważniejszą korzyść duchową wyprawy, czyli odpuszczenie grzechów osiągalne dla tych, którzy wezmą udział w krucjacie osobiście lub wesprą ją finansowo. Gdy katalońscy krzyżowcy przygotowywali się do spotkania z wrogiem pod Portopi, w królewskim namiocie odprawiono mszę. Biskup Barcelony Berenguer wygłosił kazanie, stwierdzając m.in., że krucjata jest dziełem Bożym. „Ci, którzy zginą, zginą za naszego Pana i zdobędą raj, gdzie czeka ich wieczna chwała. Ci, którzy przeżyją, także zyskają sławę i chwałę za życia oraz dobrą śmierć"23. Działania wojenne miały bogatą oprawę liturgiczną, służącą podniesieniu na duchu i usprawiedliwieniu prowadzonej akcji. Kaznodzieje nie tylko zapewniali żołnierzy, że Bóg stoi po ich stronie oraz udziela im opieki i pomocy, ale także przekonywali, że toczona przez nich

${ }_{21}$ M. Lenart, Miles pius et iustus. Żołnierz chrześcijański katolickiej wiary w kulturze i piśmiennictwie dawnej Rzeczypospolitej (XVI-XVIII w.), Warszawa 2009, s. 102.

22 J. Longère, La prédication médiévale, dz. cyt., s. 175.

23 J. F. O'Callaghan, Rekonkwista. Krucjaty w średniowiecznej Hiszpanii, przekł. J. Szkudliński, Poznań 2016, s. 289. 
wojna jest wojną sprawiedliwą i miłą Bogu. Niekiedy kaznodzieje ogłaszali też krzyżowcom odpuszczenie grzechów. W czasie bitwy wzywano Boga i świętych, wielu zaś było gotowych uwierzyć w każdą pogłoskę o bezpośredniej nadprzyrodzonej interwencji. Po zwycięstwie śpiewano hymny dziękczynne i przystępowano do ponurego zadania, jakim było pogrzebanie zabitych. Choć śmierć towarzyszy napełniała smutkiem, wierzono, że wszyscy oni trafili do nieba jako męczennicy ${ }^{24}$.

Kaznodziejstwo wędrowne i krucjatowe sprawiły, iż słynni mówcy od XIII do XV wieku zaczęli nauczać poza świątynią w miejscach często uczęszczanych przez ludzi. W tym celu ustawiano kazalnice jako obiekty wolno stojące. Do dziś na zachodzie Francji zachowały się takie ambony z tych czasów, umieszczone na zewnątrz kościoła, np. przy katedrze w Tours, przy kościołach Notre-Dame de Vitré, Saint-Aubin-de Guérande. Na słynne misje Wincentego Ferrera OP w Bretanii (14181419) władze kościelne wybrały miejsca także poza świątyniami: przy murach miejskich w Rennes, plac katedralny i cmentarz św. Mikołaja w Nantes ${ }^{25}$. Takie oddalenie kazalnicy od ołtarza zapoczątkowało autonomizację przepowiadania i oderwanie go od liturgii mszy świętej ${ }^{26}$. Jednakże tylko w ten sposób można było dotrzeć z głoszonym słowem Bożym do ogromnych rzesz słuchaczy. Jedyną przeszkodą dla tego typu kaznodziejstwa były niekorzystne warunki atmosferyczne, uporczywe deszcze lub przenikliwe zimno. Wtenczas to z konieczności chroniono się w murach świątyni ${ }^{27}$.

Na rynkach miast i placach targowych lubił głosić kazania Bertold z Ratyzbony OFM (zm. 1272), jeden z najwybitniejszych kaznodziejów pokutnych średniowiecza ${ }^{28}$. Działał on głównie w południowych Niemczech, przyciągając do siebie niezliczone tłumy. Jego kazania są cennym źród-

24 J. F. O'Callaghan, Rekonkwista..., dz. cyt., s. 317-319.

25 H. Martin, Le métier de prédicateur á la fin du Moyen-Âge (1350-1520), Paris 1988, passim.

26 B. Nadolski, Ambona, historia, znaczenie, symbolika, dz. cyt., s. 22.

27 H. Martin, Le métier de prédicateur..., dz. cyt., s. 555: „Il peut arriver que la pluie ou le froid contraigne de se réfugier dans une église, mais la règle est bien de prêcher en plein air quand le temps le permet".

${ }_{28}$ Zob. R. Rusconi, De la prédication à la confession: Transmission et contrôle de modèles de comportement au XIIIe siècle, w: Faire Croire. Modalités de la diffusion et de la réception des messages religieux du XIIe au XVe siècle, Rome 1981, s. 67-85. 
łem do poznania ówczesnej obyczajowości i wierzeń ludowych; odznaczają się obrazowością, siłą wyrazu i dramatycznym napięciem; wykazał w nich znajomość Biblii, komentarzy do Pisma Świętego i summ teologicznych. Wystąpienia te, bogate w egzempla i konkretne opisy, czyniły wielkie wrażenie na współczesnych. Bertold uderzał w ton apokaliptyczny i prorocki, a upominając swych słuchaczy, odwoływał się do mocnych argumentów.

W ślad za tą praktyką szło prawodawstwo. Warto zwrócić uwagę na dekret 10 soboru w Vienne z 1312 roku, który zezwolił dominikanom i franciszkanom na głoszenie kazań na ulicach i placach miast (in plateis communibus) i nakazał dostojnikom kościelnym wszystkich stopni oraz księżom parafialnym, by nie byli temu przeciwni ${ }^{29}$. Tym samym zaznaczono, że kazanie nie musiało być już głoszone w kościele podczas mszy świętej. Dekret 10 soboru vienneńskiego legalizował spotykaną już tu i ówdzie praktykę.

Wyjątkowym miejscem głoszenia słowa Bożego był także cmentarz. Tradycja głoszenia kazań przy grobach sięga, jak już wspomniano, czasów prześladowań z pierwszych wieków i kultu męczenników w katakumbach. Za wzorem franciszkanina Ryszarda, który głosił kazania do paryżan przed kostnicą des Innocents (ok. 1430), zakonnicy bretońscy nauczali na cmentarzach. Około 1470-1480 dominikanie z Rennes i Nantes otrzymali niezbędne do tego pozwolenie. Cmentarze jako miejsca głoszenia słowa Bożego miały wiele zalet. Na ich terenie była często kaplica, mogły pomieścić dużo ludzi, a przede wszystkim oddziaływały na wyobraźnię człowieka swoją scenerią ${ }^{30}$. Średniowiecze odkryło potęgę tematu eschatologicznego w kazaniu i chętnie się nim posługiwało. Najlepszym przykładem tego jest kaznodziejstwo wspomnianego juź Wincentego Ferrera ${ }^{31}$. Często też kazania te łączono z przedstawieniami teatralnymi mającymi lepiej uzmysłowić omawianą problematykę.

Kolejnymi niezwykłymi miejscami, gdzie głoszono kazania, były królewskie i książęce dwory. Pełniona na nich missio aulica była najczęściej

${ }_{29}$ Zob. Dokumenty Soborów Powszechnych, t. 2, układ i oprac. A. Baron, H. Pietras, Kraków 2004, s. 549.

30 J. Longère, La prédication médiévale, dz. cyt., s. 175.

31 Zob. cenną monografię: P. Dobrowolski, Wincenty Ferrer - kaznodzieja ludowy późnego średniowiecza, Warszawa 1996. 
podejmowana przez specjalnie powoływanych do tych zadań kaznodziejów dworskich. Kazania głoszono z różnych okazji. Przy zawieraniu małżeństwa królewskiego czy książęcego powstawały epitalamia, a z okazji śmierci członka rodziny epicedia. Uroczystościom dworskim towarzyszyła bogata oprawa ceremonialna, godna majestatu królewskiego czy książęcego ${ }^{32}$.W części religijnej odprawiano uroczystą mszę świętą z okolicznościowym kazaniem. Często były to wystąpienia o dużym znaczeniu.

Ciekawym przykładem kazań dworskich są mowy głoszone podczas turniejów rycerskich, w których udział notabene był ostro potępiany przez Kościół jako niepotrzebne narażanie życia. Rzecz jasna określonych słuchaczy poszukiwano tam, gdzie oni się gromadzili ${ }^{33}$. Skłaniała do tego również potrzeba dotarcia do odbiorców, którzy by nie przyszli słuchać słowa Bożego w kościele.

Z chwilą powstania ważnym miejscem głoszenia słowa Bożego stały się uniwersytety. Organizacja i praktyka kaznodziejstwa uniwersyteckiego ustaliły się na uniwersytecie paryskim i wzór ten naśladowano w innych uniwersytetach europejskich. Społeczność uniwersytecka (studenci czterech wydziałów, mistrzowie i bakałarze) była obowiązana do uczestniczenia w religijnych uroczystościach, organizowanych przez władze uniwersyteckie. Należały do nich procesje, msze uniwersyteckie, kazania. Kazania uniwersyteckie były głoszone w niedziele i święta obchodzone przez cztery wydziały. Wieczorem tego samego dnia bakałarze głosili kazania wieczorne (collatio) na temat rannego kazania mistrza. Językiem tych kazań była łacina, znana z codziennych wykładów i dostępna międzynarodowej społeczności studentów. Kazanie uniwersyteckie przypominało wykład, ujęty w precyzyjne podziały treści. Obfitowało w subtelne

32 S. Kutrzeba, Źródła polskiego ceremoniału koronacyjnego, „Przegląd Historyczny” 12 (1911), s. 71-83, 149-164, 285-307; A. Gieysztor, Spektakl i liturgia - polska koronacja królewska, w: Kultura elitarna a kultura masowa w Polsce późnego średniowiecza, red. B. Geremek, Wrocław 1978, s. 9-23.

33 Podkreśla to Ch. T. Maier, Preaching the crusades. Mendicant friars and the cross in the thirteenth century, Cambridge 1994, s. 107: „Crusade preachers also tried to make use of events where people had come together for other reasons. Thus in 1236 a Dominican crusade preacher delivered a sermon before King Henry III and an assembly of English noblemen in Winchester. John of Wildeshausen and William of Cordelle were both reported to have preached at tournaments". 
dociekania, z wyraźną tendencją do częstego odwoływania się do tekstu Pisma Świętego i zdań autorytetów. Obowiązek głoszenia kazań nakładały statuty uniwersyteckie i one dawały prawo do wystąpienia na ambonie, chociaż mistrzowie albo bakałarze często nie mieli święceń kapłańskich. Dlatego też Piotr Cantor podkreślał, że licentia praedicandi magistra teologii nie pochodzi z władzy święceń kapłańskich, lecz z tytułu naukowego ${ }^{34}$.

Dobrym podsumowaniem miejsc głoszenia słowa Bożego w późnym średniowieczu i pierwszych latach epoki nowożytnej może być analiza kaznodziejstwa francuskiego przeprowadzona przez profesora Hervé Martina. Śledząc kroniki i rachunki miejskie za lata 1350-1520, wyodrębnił on 290 miejsc, w których głoszone były kazania odnotowane w tych źród$ł \mathrm{ach}^{35}$. Naich podstawie doszedł dobardzo ciekawych wniosków.Zestawienie tych loci dało ciekawe rezultaty, które uwidacznia poniższa tabela:

\begin{tabular}{|l|l|}
\hline \multicolumn{1}{|c|}{ MIEJSCE GEOSZENIA } & LICZBA WYSTĄPIEŃ \\
\hline kościoły parafialne & 104 \\
\hline katedry & 48 \\
\hline place przykatedralne & 5 \\
\hline opactwa & 19 \\
\hline klasztory & 39 \\
\hline kapitularze & 1 \\
\hline leprozoria & 1 \\
\hline dwory królewskie lub książęce & 5 \\
\hline siedziby biskupie & 2 \\
\hline kaplice & 9 \\
\hline place publiczne & 20 \\
\hline hale & 5 \\
\hline jarmarki & 1 \\
\hline wielkie procesje (poza kościołem) & 19 \\
\hline u stóp krzyża & 2 \\
\hline cmentarze & 7 \\
\hline szubienica lub pręgierz & 2 \\
\hline otwarta przestrzeń (poza miejscem zamieszkania) & 1 \\
\hline
\end{tabular}

34 K. Panuś, Historia kaznodziejstwa, dz. cyt., s. 118-121.

35 H. Martin, Le métier de prédicateur..., dz. cyt., s. 552-555. 
W świetle powyższego do znanych już miejsc głoszenia słowa Bożego, takich jak: kościoły, dwory królewskie, place miejskie i otwarta przestrzeń poza miejscem zamieszkania, doszły nowe, takie jak: leprozoria, szpitale i miejsca wykonywania kary (szubienica lub pręgierz), gdzie na przykładzie skazańców, przestrzegano przed wejściem na drogę występku i wzywano do postępowania drogą cnoty. Jednakże sam Martin przyznaje, że w rzeczywistości znacznie częściej, niż na to wskazuje powyższa tabela, głoszono kazania poza obiektami sakralnymi, zwłaszcza na cmentarzach ${ }^{36}$.

\section{Miejsca głoszenia słowa Bożego w Polsce}

W świetle tego, co zostało już powiedziane, warto zastanowić się, jak było z głoszeniem słowa Bożego w Polsce. Chociaż nie zachował się materiał dowodowy służący rekonstrukcji scenariusza polskiego kazania średniowiecznego, to jednak z okruchów informacji rozsianych po różnorodnych źródłach wynika, że pierwsze kazania na ziemiach polskich były wygłaszane pod gołym niebem, zazwyczaj w miejscu większych skupisk ludności ${ }^{37}$. Żywoty św. Wojciecha (Vita prior i Vita alterior) ${ }^{38}$ podają, że podczas podróży misyjnych przemawiał on na targowiskach i na placach wiecowych. Ta naturalna sceneria połączona z obecnością wielu różnych osób towarzyszących misjonarzowi, głównie chroniącej go drużyny rycerskiej, stwarzała dodatkowe bodźce dla odbioru żywego słowa. Po przeprowadzonym w danej miejscowości lub okręgu kilkutygodniowym przygotowaniu misjonarze odbierali od słuchaczy słowne wyrzeczenie się dawnych bóstw i wierzeń (abrenuntiatio diaboli) oraz wyznanie wiary chrześcijańskiej (confessio fidei), po czym udzielali im chrztu świętego ${ }^{39}$.

\footnotetext{
36 H. Martin, Le métier de prédicateur..., dz. cyt., s. 553.

37 K. Panuś, „Kościót przyniósł Polsce Chrystusa” (Jan Paweł II). Rola kaznodziejstwa w chrystianizacji Polski, „Warszawskie Studia Pastoralne”, wyd. specjalne, Polska krajem misyjnym? 1050 lat chrześcijaństwa w Polsce, red. T. Wielebski, P. Ochotny, M. J. Tutak, Warszawa 2016, s. 40.

38 W kręgu żywotów świętego Wojciecha, red. nauk. J. A. Spież, Kraków 1997, s. 28.

39 K. Ożóg, 966. Chrzest Polski, Kraków 2016, s. 116.
} 
Znane z tradycji zachodnioeuropejskiej kazania na rynkach i placach miast znalazły $\mathrm{w}$ Polsce wybitnego reprezentanta w osobie św. Jana Kapistrana. Warto przytoczyć relację kronikarza Jana Długosza z jego wystąpień na rynku krakowskim. Według niej słynnemu franciszkaninowi, przybyłemu w sierpniu 1453 roku do stolicy Królestwa Polskiego, na rynku, „w pobliżu kościoła św. Wojciecha, wzniesiono podwyższenie, na którym codziennie, dopóki nie nadeszły ostre mrozy, po odprawieniu Mszy głosił słowo Boże po łacinie, zgodnie ze swym zwyczajem przez dwie godziny, a prosty lud słuchał i nie nudził się. Obdarzony był rozsądkiem, wymową i wiedzą, że wydawało się, iż mówi z rozwagą i językiem niebiańskim. Jego kazanie przez następne dwie godziny powtarzano w języku ludu. W ten sposób każdego dnia kazanie trwało bez przerwy przez cztery godziny. Kiedy zaś nadeszły mrozy, podwyższenie umieszczono w kościele Panny Maryi w pobliżu tabernakulum i nadal codziennie głoszono kazanie, najpierw po łacinie, a potem w języku ludu"40. W opisie Długosza jest kilka zastanawiających szczegółów. Trudno dziś powiedzieć, za pomocą jakich środków kaznodzieja potrafił utrzymać zainteresowanie i uwagę słuchaczy w czasie kazania głoszonego po łacinie? Może elementem decydującym był głos i gestykulacja mówcy, może jakieś inne czynniki zewnętrzne towarzyszące akcji oratorskiej. Faktem jest jednak, że płomienne kazania Jana odnosiły nieprawdopodobny skutek ${ }^{41}$.

Do znanych już miejsc, w których głoszono słowo Boże, trzeba jeszcze dopisać jedno - pole bitwy, na którym kapłan stawał, zagrzewając wojsko do walki. Szczególnie mocna była tradycja grunwaldzka w kaznodziejstwie. Wiadomo, że w czasie pochodu wojsk królewskich na pole słynnej bitwy kazanie z wątkami wykładu o wojnie sprawiedliwej i niesprawiedliwej wygłosił biskup płocki Jakub ${ }^{42}$. Niestety tekstu tego kazania nie

40 Cyt. za: M. Korolko, O kunszcie oratorskim staropolskiego kaznodziejstwa, w: Kultura żywego słowa w dawnej Polsce, Warszawa 1989, s. 64-65.

${ }_{41}$ W. Murawiec, Kaznodzieja podróżujący i reformator, „Studia Franciszkańskie” 3 (1988), s. $273-294$.

42 „Iacobus autem Plocensis episcopus [...] sermonem eciam in vulgari Polonico aput uniwersum exercitum [...] habuit multaque de bello iusto et iniusto, cum esset vir rare literature habens donum sermonis, disserens [...] bellum regium contra Cruciferos assumptum iustissimum fiore deduxit”. Zob. Ioannis Dlugossii, Annales, lib. X-XI (przyp. 12), s. 65. 
znamy. Natomiast kazaniem założycielskim tradycji grunwaldzkiej w kaznodziejstwie polskim w sensie ideowym jest słynna mowa Stanisława ze Skarbimierza De bellis iustis, zredagowana przed bitwą lub wkrótce po niej. Prawdziwa fala wystąpień kaznodziejskich wylała się jednak po bitwie, jednak nie od razu, lecz w powolnym procesie rozwoju kaznodziejskiej inwencji ${ }^{43}$.

Liczne wojny toczone przez Rzeczpospolitą Obojga Narodów sprawiły, że kazania głoszone w obozach wojskowych miały doniosły charakter. Znajdowały się one w dorobku najwybitniejszych kaznodziejów polskich, takich jak: ks. Piotr Skarga SJ, Fabian Birkowski OP, Jakub Olszewski SJ i wielu innych. Kazania obozowe głoszone przed bitwą dodawały odwagi, budziły wiarę w zwycięstwo i słuszność prowadzonej walki. Fabian Birkowski, oceniając dokonania innego wielkiego kaznodziei królewskiego - Stanisława Sokołowskiego, podkreślał ogromną rolę jego kazań w budzeniu wśród żołnierzy bohaterstwa i poświęcenia. „Te bohaterskie serca wojną oddychające, na odgłos kazania w takie wpadły zachwycenie, że zdawały się zapominać swoich spraw rycerskich. Ale po zakończeniu kazania taki widziałeś w rycerstwie zapał i tak bohaterską pogardę śmierci, że nowi na obronę chrześcijaństwa zdawali się powstawać templariusze" 44 . W podobnym duchu w kazaniu obozowym zachęcał wojsko ks. Piotr Skarga: „Dziś bitwę zwiedziecie z nieprzyjaciółmi waszemi. Niech się serce wasze nie lęka, nie bójcie się, nie ustępujcie, nie bójcie się ich! Bo Pan Bóg wasz jest z wami i on za wami przeciw nieprzyjaciołom walczyć będzie, aby was wyrwał z niebezpieczeństwa. [...] Jedno to uczyńcie, co on kazał. Żałujcie za grzechy swoje a skruchę w sobie wzbudzajcie [...]. Do spowiedzi i rozgrzeszenia kapłańskiego pójdźcie. [...] Kto kogo obraził, odpuszczaj z całego serca a mścić się żaden nie myśl

Por. Z. Kozłowska-Budkowa, Uniwersytet Jagielloński w dobie Grunwaldu, „Zeszyty Naukowe Uniwersytetu Jagiellońskiego”. Prace Historyczne, nr 48 (1961) z. 8, s. 63.

43 K. Bracha, Święto wiktorii grunwaldzkiej w kaznodziejstwie polskim późnego średniowiecza, w: Conflictus magnus apud Grunwald 1410. Między historia a tradycją. Materiały z międzynarodowej konferencji naukowej „Grunwald - Tannenberg - Žalgiris” zorganizowanej 20-24 września 2010 r. w Malborku i Krakowie, red. K. Ożóg, J. Trupinda, Malbork 2013, s. 237.

${ }_{44}$ F. Birkowski, Anniversarium Stan. Socolovii, Kraków 1622, s. 7. 
[...]. To uczyniwszy, bieżcie do serca śmiałość, a proście jej od Pana Boga, aby wam dał męstwo i wielkie serce na tę swoją posługę"45.

W ślad za praktyką zachodnioeuropejską w Polsce głoszono także kazania na cmentarzach. Pozostałością tych zwyczajów są dzisiejsze kazania w Uroczystość Wszystkich Świętych i w Dzień Zaduszny.

W polskiej tradycji kaznodziejskiej duże znaczenie odgrywają kazania sejmowe ${ }^{46}$. Słuchali ich posłowie i senatorowie w trakcie obrad sejmów, ale miejscem ich wygłoszenia nie był sejm. Zresztą aż do końca istnienia I Rzeczypospolitej nie było odrębnego budynku parlamentu, lecz obradowano na zamku królewskim. Stąd też nabożeństwa na początku i przy końcu posiedzeń odprawiano w katedrze wawelskiej, jeśli sejm miał miejsce w Krakowie, lub w kolegiacie Świętego Jana, jeśli obradowano w Warszawie. W obradach uczestniczył król wraz z posłami i senatorami. Wszyscy oni brali udział w nabożeństwach odprawianych w niedziele oraz w inne święta przypadające w trakcie obrad. Wysłuchiwano wtedy kazań, których głoszenie już za czasów Stefana Batorego powierzano (choć nie zawsze) kaznodziejom królewskim, a ci dotykali głównie palących spraw życia narodowego i religijnego. Zresztą oddzielenie spraw polityki od religii było wówczas praktycznie niemożliwe. Kaznodziejstwo polityczne w Polsce osiąga swe szczyty w drugiej połowie XVI wieku. U jego podstaw leżało przekonanie, że zasadom etyki chrześcijańskiej winno być podporządkowane nie tylko życie indywidualne, lecz również państwowe, polityczne i społeczne. Przynajmniej od XV wieku panowało przekonanie o istnieniu szczególnych, sięgających czasów biblijnych związków między Bogiem a narodem polskim ${ }^{47}$. Zrozumiałe jest więc, że tematyka społeczno-polityczna była szczególnie żywa w centrum władzy, w stolicy i stąd też często pojawiała się w kazaniach głoszonych wobec króla i jego dostojników obecnych na sejmie. Do najbardziej znanych należy osiem Kazań sejmowych Piotra Skargi, dołączonych do drugiego wydania Kazań na niedziele i święta (Kraków 1597). Chociaż jezuicki ka-

45 P. Skarga, Kazania o siedmiu sakramentach..., Kraków 1600, s. 243.

46 M. Korolko, Uwagi o genologii kazania politycznego w Polsce XVI w., w: Kultura i literatura dawnej Polski, Warszawa 1968, s. 163.

${ }_{47}$ M. Brzozowski, Tematyka polityczna w polskich kazaniach katolickich w XVII wieku, „Przegląd Powszechny” 4 (1982), s. 106. 
znodzieja nigdy ich nie wygłosił w tej postaci, mogły się w nich znaleźć pewne fragmenty wcześniej już powstałe i naprawdę wygłoszone. Pisząc swój traktat, autor miał już olbrzymią praktykę kaznodziejską, z której pozostało mu bez wątpienia sporo notatek czy nawet gotowych tekstów. Zabierał bowiem głos podczas trwania sejmów, a pierwsze tego typu kazanie wygłosił już 1 maja 1572 roku w Warszawie ${ }^{48}$.

Także w działalności kaznodziejskiej Mateusza Bembusa SJ (zm. 1645) znajdują się kazania wygłoszone podczas mszy inaugurujących prace sejmu. W rękopisie zawierającym diariusz sejmowy znajdującym się w Archiwum Państwowym w Gdańsku (sygn. 300/29/90, k. 102) zachowało się streszczenie kazania sejmowego z 26 kwietnia 1616 roku: „Przed podniesieniem słynny kaznodzieja królewski jezuita Mateusz Bembus wygłosił kazanie w języku polskim. Starając się skłonić posłów do pozytywnego ustosunkowania się do propozycji królewskich, Bembus położył nacisk na cztery sprawy. Zwracał uwagę, że w obecnej sytuacji dla dobra pokoju nie należy kwestionować praw religii katolickiej, trzeba mieć na względzie dobro publiczne, zachować wierność królowi i radzić sine respectu commodi privati" 49 .

Podobny co kazania sejmowe charakter miały mowy trybunalskie wygłaszane w kościołach z okazji posiedzeń Trybunału Koronnego w Lublinie bądź Trybunału Wielkiego Księstwa Litewskiego w Grodnie lub Wilnie. Kaznodziejstwo polityczne miało na celu propagowanie haseł politycznych epoki oraz było środkiem kształtowania ówczesnego patriotyzmu ${ }^{50}$. Jako kaznodzieje trybunalscy w Lublinie w XVII wieku zasłynęli Kasper Drużbicki i Tomasz Młodzianowski, zaś w XVIII wieku jako kaznodzieja Trybunału Koronnego odbywającego posiedzenia sądowe w Poznaniu i w Piotrkowie wsławili się Marceli Jurkiewicz OFMConv (ok. 1735-1791) oraz Michał Karpowicz. Ten ostatni między rokiem 1775 i 1792 wygłosił ich ponad dwadzieścia, głównie w Grodnie, podczas trwania kadencji ru-

48 J. Tazbir, Skarga Piotr (1536-1612), w: Polski słownik biograficzny, t. 38, s. 35-43; K. Panuś, Ks. Piotr Skarga, Kraków 2012, s. 70-76.

49 Zob. S. Ochmann, Sejmy z lat 1615-1616, Wrocław 1970, s. 156; M. Barłowska, Wstęp, w: M. Bembus, Wizerunek szlachcica prawdziwego w kazaniu na pogrzebie Andrzeja Boboli, Warszawa 2016, s. 9.

50 M. Korolko, Uwagi o genologii kazania politycznego..., dz. cyt., s. 170. 
skiej Trybunału Wielkiego Księstwa Litewskiego i wyjątkowo w Wilnie, podczas kadencji litewskiej. Większość z nich na wyraźną prośbę słuchaczy została wydrukowana. Cieszyły się one dużą popularnością. Cenzury kościelne tych kazań podkreślały zarówno ich walory retoryczne, jak religijne i obywatelskie - oceniano je jako wzorcowe ${ }^{51}$.

\section{Podsumowanie}

Podsumowując powyższe rozważania na temat miejsc głoszenia słowa Bożego, najpierw należy podkreślić niezwykłą inwencyjność Jezusa z Nazaretu, który nauczał nie tylko w świątyni jerozolimskiej i w synagogach, ale także pod gołym niebem, z łodzi, w domach i w czasie uczty. W ślad za tym szła praktyka apostolska oraz nauczanie Kościoła pierwszych wieków. $Z$ upływem stuleci chrześcijanie zbudowali imponujące świątynie ze wspaniałymi ambonami służącymi proklamacji słowa Bożego. Nigdy jednak głoszenie kazań nie ograniczało się tylko do miejsc kultu. W poszukiwaniu słuchacza kaznodzieje udawali się bądźtam, gdzie on żył i działał: na pola bitew, na place miast, jarmarki, miejsca wykonywania kar, do leprozoriów i szpitali, bądź tam, gdzie człowiek znajdował miejsce wiecznego spoczynku - na cmentarze. Praktyka głoszenia słowa Bożego w Polsce koncentrowała się również w tych samych miejscach. Czasy najnowsze niewiele do tego dorzuciły. Największe bowiem zgromadzenia wiernych, niejednokrotnie kilkumilionowe, w czasie których głoszono słowo Boże, jak pielgrzymki papieskie czy Światowe Dni Młodzieży, miały swych prekursorów w kaznodziejskiej działalności wspomnianych wyżej świętych - Jana Kapistrana czy Wincentego Ferrera.

${ }^{51}$ K. Panuś, Zarys historii kaznodziejstwa w Kościele katolickim, cz. 2: Kaznodziejstwo w Polsce-Od oświecenia do XX wieku, Kraków 2001, s. 85-91. 


\section{Summary}

\section{Miejsca przepowiadania słowa Bożego. Panorama historyczna}

Słowo Boże głoszone było nie tylko w miejscach kultu. Sam Jezus, niedościgły wzór wszystkich kaznodziejów, głosił je także na otwartej przestrzeni, z łodzi, w domach i w czasie uczty. W ślad za Jego wzorem szła praktyka apostolska oraz nauczanie Kościoła pierwszych wieków. Z upływem stuleci chrześcijanie zbudowali imponujące świątynie ze wspaniałymi ambonami służącymi proklamacji słowa Bożego. Nigdy jednak głoszenie kazań nie ograniczało się wyłącznie do miejsc kultu. W poszukiwaniu słuchacza kaznodzieje udawali się bądź tam, gdzie on żył i działał: na pola bitew, na place miast, jarmarki, miejsca wykonywania kar, do leprozoriów i szpitali, bądź tam, gdzie człowiek znajdował miejsce wiecznego spoczynku na cmentarze. Praktyka głoszenia słowa Bożego w Polsce również koncentrowała się $\mathrm{w}$ tych samych miejscach. Czasy najnowsze niewiele do tego dorzuciły. Największe bowiem zgromadzenia wiernych, niejednokrotnie kilkumilionowe, w czasie których głoszono słowo Boże - jak pielgrzymki papieskie czy Światowe Dni Młodzieży - miały swych prekursorów w kaznodziejskiej działalności świętych: Jana Kapistrana czy Wincentego Ferrera.

Słowa kluczowe: historia kaznodziejstwa, miejsca przepowiadania, słowo Boże

\section{The Places of Preaching the Word of God. The Historical Panorama}

Following Jesus Christ who preached the Word of God not only in the places of worship, but also in open space, from a boat, in houses or during feasts, there was an apostolic practice and the teaching of the Church of the first centuries. With the passing of centuries the Christians built impressive shrines with wonderful pulpits designed for the proclamation of the Word of God. However, never has preaching been limited to the places of worship. While searching for the listeners the preachers used to go to places where they lived and worked: battlefields, town squares, markets, places of execution, leprosariums and hospitals or where a man crossed the great divide - cemeteries. The practice of preaching the Word of God in Poland was also concentrated in the same places. Modern times have not added much to it. The biggest assemblages of the faithful, often of several million, during which the Word of God was preached, such as Pope pilgrimages, or the World Youth Day, had their forefathers in the preaching activity of the Saints, i.e. John Capistrano, or Vincent Ferrer.

Keywords: history of preaching, places of preaching, the Word of God 


\section{Bibliografia}

Barłowska M., Wstęp, w: M. Bembus, Wizerunek szlachcica prawdziwego w kazaniu na pogrzebie Andrzeja Boboli, Warszawa 2016, s. 5-41.

Bracha K., Święto wiktorii grunwaldzkiej w kaznodziejstwie polskim późnego średniowiecza, w: Conflictus magnus apud Grunwald 1410. Między historia a tradycja. Materiały z międzynarodowej konferencji naukowej „Grunwald - Tannenberg - Žalgiris” zorganizowanej 20-24 września 2010 r. w Malborku i Krakowie, red. K. Ożóg, J. Trupinda, Malbork 2013, s. 231-247.

Brzozowski M., Tematyka polityczna w polskich kazaniach katolickich w XVII wieku, „Przegląd Powszechny” 4 (1982), s. 106-116.

Daniélou J., Marrou H. I., Historia Kościoła, t. 1: Od początków do roku 600, tłum. M. Tarnowska, Warszawa 1986.

Dobrowolski P., Wincenty Ferrer - kaznodzieja ludowy późnego średniowiecza, Warszawa 1996.

Dokumenty Soborów Powszechnych, t. 2, układ i oprac. A. Baron, H. Pietras, Kraków 2004.

Ewangelia według św. Mateusza, wstęp, przekład z oryginału, komentarz - oprac. J. Homerski, Poznań-Warszawa 1979.

Gieysztor A., Spektakl i liturgia - polska koronacja królewska, w: Kultura elitarna a kultura masowa w Polsce późnego średniowiecza, Wrocław 1978, s. 9-23.

Iwaszkiewicz-Wronikowska B., Katakumby, w: Encyklopedia katolicka, t. 8, red. A. Bednarek i in., Lublin 2000, s. 978-982.

Korolko M., Uwagi o genologii kazania politycznego w Polsce XVI w., w: Kultura i literatura dawnej Polski, Warszawa 1968, s. 151-172.

Korolko M., o kunszcie oratorskim staropolskiego kaznodziejstwa, w: Kultura żywego słowa w dawnej Polsce, Warszawa 1989, s. 56-99.

Kozłowska-Budkowa Z., Uniwersytet Jagielloński $w$ dobie Grunwaldu, „Zeszyty Naukowe Uniwersytetu Jagiellońskiego", Prace Historyczne, nr 48 (1961) z. 8, s. 55-71.

Kutrzeba S., Źródła polskiego ceremoniału koronacyjnego, „Przegląd Historyczny” 12 (1911), s. 71-83, 149-164, 285-307.

Lenart M., Miles pius et iustus. Żołnierz chrześcijański katolickiej wiary w kulturze i piśmiennictwie dawnej Rzeczypospolitej (XVI-XVIII w.), Warszawa 2009.

Longère J., La prédication médiévale, Paris 1983.

Maier Ch. T., Preaching the crusades. Mendicant friars and the cross in the thirteenth century, Cambridge 1994.

Martin H., Le métier de prédicateur á la fin du Moyen-Âge (1350-1520), Paris 1988.

Murawiec W., Kaznodzieja podróżujący i reformator, „Studia Franciszkańskie” 3 (1988), s. 273-294.

Nadolski B., Ambona, historia, znaczenie, symbolika, Kraków 2008.

O'Callaghan J. F., Rekonkwista. Krucjaty w średniowiecznej Hiszpanii, przekł. J. Szkudliński, Poznań 2016. 
Ochmann S., Sejmy z lat 1615-1616, Wrocław 1970.

Olivar A., Predicazione: Nella Chiesa Antica, w: Dizionario di Omiletica, a cura di M. Sodi, A. M. Triacca, Torino-Bergamo 1998, s. 1218.

Ożóg K., 966. Chrzest Polski, Kraków 2016.

Panuś K., Zarys historii kaznodziejstwa w Kościele katolickim, cz. 1: Kaznodziejstwo w Kościele powszechnym, Kraków 1999; cz. 2: Kaznodziejstwo w Polsce - Od oświecenia do XX wieku, Kraków 2001.

Panuś K., Historia kaznodziejstwa, Kraków 2007.

Panuś K., Ks. Piotr Skarga, Kraków 2012.

Panuś K., „Kościót przynióst Polsce Chrystusa” (Jan Paweł II). Rola kaznodziejstwa w chrystianizacji Polski, „Warszawskie Studia Pastoralne”, wyd. specjalne, Polska krajem misyjnym? 1050 lat chrześcijaństwa w Polsce, red. T. Wielebski, P. Ochotny, M. J. Tutak, Warszawa 2016, s. 37-62.

Radej M., Istotne problemy kaznodziejskie, Kraków 2013.

Runciman S., Dzieje wypraw krzyżowych, t. 1: Pierwsza krucjata i założenie Królestwa Jerozolimskiego, t. 2: Królestwo Jerozolimskie i frankijski Wschód 1100-1187, przekł. J. Schwakopf, Warszawa 1987.

Rusconi R., De la prédication à la confession: Transmission et contrôle de modèles de comportement au XIIIe siècle, w: Faire Croire. Modalités de la diffusion et de la réception des messages religieux du XIIe au XVe siècle, Rome 1981, s. 67-85 (Collection de l'École Française de Rome, 51).

Siwek G., Interpretacja homiletyczna miejsc przepowiadania w przestrzeni kościelnej, „Analecta Cracoviensia” 36 (2004), s. 293-317.

Snela B., Ambona, w: Encyklopedia katolicka, t. 1, red. F. Gryglewicz, R. Łukaszyk, Z. Sułowski, Lublin 1973, s. 407-408.

Staniek E., Ewangeliczne uczty, Kraków 2008.

Tazbir J., Skarga Piotr (1536-1612), w: Polski słownik biograficzny, t. 37, s. 35-43.

W kręgu żywotów świętego Wojciecha, red. nauk. J. A. Spież OP, Kraków 1997. 